\title{
Regulation of thymosin $\beta 10$ expression by TSH and other mitogenic signals in the thyroid gland and in cultured thyrocytes
}

\author{
Giuseppe Viglietto, Daniela Califano, Paola Bruni, Gustavo Baldassarre, Maria Teresa Vento, Barbara Belletti, \\ Monica Fedele, Giovanni Santelli, Angelo Boccia, Giovanni Manzo, Massimo Santoro ${ }^{2}$ and Alfredo Fusco ${ }^{1}$ \\ Istituto Nazionale dei Tumori di Napoli, Fondazione Senatore Pascale, Via M. Semmola, 80131 Napoli, Italy, ${ }^{1}$ Dipartimento di Medicina Sperimentale \\ e Clinica, Facoltà di Medicina e Chirurgia di Catanzaro, Università di Reggio Calabria, via Tommaso Campanella, 88100 Catanzaro, Italy and \\ ${ }^{2}$ Dipartimento di Biologia e Patologia Cellulare e Molecolare c/o Centro di Endocrinologia ed Oncologia Sperimentale del CNR, Facoltà di Medicina e \\ Chirurgia di Napoli, Università degli Studi di Napoli 'Federico II', via Pansini, 5, 80131 Napoli, Italia \\ (Correspondence should be addressed to A Fusco, Dipartimento di Biologia e Patologia Cellulare e Molecolare, Facoltà di Medicina e Chirurgia di \\ Napoli, Università degli Studi di Napoli 'Federico II', via Pansini, 5, 80131 Napoli, Italy)
}

\begin{abstract}
Objective: To investigate the expression of thymosin $\beta 10$ - a small conserved acidic protein involved in the inhibition of actin polymerization - in human and experimental thyroid goiters as well as the regulation exerted by TSH on thymosin $\beta 10$ expression in thyroid follicular cells both in vivo and in vitro.

Design: To this aim, we have used 5 bioptic specimens from patients affected by thyroid goiter, a well known experimental model of thyroid goitrogenesis (rat fed with the drug propylthiouracil) and a cultured rat thyroid cell line (PC Cl 3 cells) as a model system.

Results: We report that the mRNA expression of thymosin $\beta 10$ is markedly enhanced in human goiters compared with normal thyroid. In vivo results showed that the steady-state level of thymosin $\beta 10$ mRNA is up-regulated in the thyroid gland of propylthiouracil-fed rats in parallel with follicular cell proliferation: iodide administration to goitrous rats, which induced a marked involution of thyroid hyperplasia, reduced the mRNA level of thymosin $\beta 10$. Finally, in vitro studies showed that in cultured rat thyrocytes, the expression of thymosin $\beta 10 \mathrm{mRNA}$ is induced in a time- and dose-dependent manner by the activation of pathways which are mitogenic for thyroid cells (i.e. the protein kinase (PK) A and PKC pathways).

Conclusion: Taken together, the findings reported here demonstrate that thymosin $\beta 10$ expression is regulated by extracellular signals that stimulate growth of thyroid cells both in vitro and in vivo, and suggest a role for this protein in thyroid diseases characterized by proliferation of follicular cells.
\end{abstract}

European Journal of Endocrinology 140 597-607

\section{Introduction}

Enlargement of the thyroid gland during the development of goiters is characterized by extensive follicular cell hyperplasia associated with the occurrence of an abnormal hypervascularization (1).

Previous studies performed with experimental induction of iodide deficiency and/or antithyroid drugs (such as propylthiouracil) treatment of animals, demonstrated that increased pituitary secretion of thyrotropin (TSH) induced thyroid cell hyperplasia and a marked hypervascularization (2-4). The development of thyroid goiters involves dramatic modifications of the morphology and of the functions of both parenchymal and endothelial cells. The initial response to an increase of serum TSH consists essentially of follicular cell hypertrophy, loss of colloid and endothelial cell proliferation.
The mitotic activity of thyrocytes dramatically increases with a peak after 7-10 days from the beginning of the treatment; as a consequence, a huge increase in the total thyroid cell mass with development of a highly vascularized goiter occurs within a few weeks $(2-4)$. Subsequent iodide administration to goitrous rats induces a rapid and marked involution of thyroid hypervascularity, followed by the regression of thyroid cell hyperplasia (5).

Such striking modifications of the morphology and of the functions of thyroid parenchymal or endothelial cells involves extensive remodeling of the cytoskeleton (6). Most molecules involved in the remodeling of cell skeletal structures remain to be defined; however, actin is likely to play a pivotal role in the maintenance of the structure and function of cells, since the dynamic equilibrium between monomeric 
and polymerized actin is crucial for cell motility and mitosis (7-9).

The $\beta$-thymosin family comprises small, highly conserved acidic proteins, which bind monomeric G-actin in vitro (10). Originally, thymosins were proposed to have immunomodulatory functions (11). However, subsequent studies suggested that $\beta$-thymosins may also have functions common to most cells (12). A recently proposed role for $\beta$-thymosins is the regulation of the cytoskeleton. In fact, thymosins $\beta 4$ and $\beta 10$ were shown to bind monomeric G-actin in vitro and in vivo, and thus to inhibit actin polymerization into stress fibers $(13,14)$ which, in turn, determine cell shape, exocytosis and the formation of adhesion plaques.

A number of investigations indicate that the expression of $\beta$-thymosins is relatively high in actively proliferating cells, and that terminal differentiation provokes changes in the relative abundance of these proteins (15-21). Accordingly, the expression of thymosin $\beta 10$ has been shown to be enhanced in different human tumors $(22,23)$ whereas the expression of thymosin $\beta 15$ is enhanced in prostate cancer (24). In particular, it seems that thymosins $\beta 4$ and $\beta 10$ may play a role in the process of thyroid tumor development, since we have recently shown that thymosin $\beta 10$ is highly over-expressed in human and experimental thyroid tumors (25), and other groups have observed increased expression of thymosin $\beta 4$ in autoimmune thyroid diseases (Graves' and Hashimoto's disease) and in medullary thyroid carcinomas $(26,27)$.

In this study we report that the mRNA expression of thymosin $\beta 10$ is markedly enhanced in human goiters compared with normal thyroid. Furthermore, we show that thymosin $\beta 10$ expression is up-regulated by propylthiouracil feeding of rats and is down-regulated by iodide administration to goitrous rats. In vitro studies showed that the activation of the protein kinase A (PKA)-dependent pathway through TSH and forskolin, of the protein kinase $C$ (PKC)-dependent pathway by 12-O-tetradecanoyl phorbol-13-acetate (TPA) and of the receptorial tyrosin kinase (RTK) pathway by insulin, exerted positive regulatory effects on the mRNA expression of thymosin $\beta 10$ in cultured rat thyrocytes. Taken together, these findings demonstrate that the expression of the thymosin $\beta 10$ gene is regulated by signals that stimulate the growth of follicular cells of the thyroid gland, and thus suggest a role for thymosin $\beta 10$ during goiter development.

\section{Materials and methods}

\section{Tissue samples}

Thyroid goiter samples were obtained after resection from patients who had undergone surgery both at the National Cancer Institute 'Fondazione Pascale', Naples, Italy and at the Laboratoire d'Histologie et de Cytologie,
Centre Hospitalier, Lyon Sud, France. Bioptic specimens were divided into two equal representative parts: one was immediately frozen in liquid nitrogen until RNA extraction was performed; the other was fixed in $4 \%$ paraformaldehyde, embedded in paraffin and then processed for pathologist diagnosis. Patients were diagnosed as having nodular goiters. All patients had elevated serum TSH levels.

\section{Cell lines and treatments}

The rat thyroid cell line $\mathrm{PC} \mathrm{Cl} 3$ used in this study is a thyroid epithelial cell line derived from 18-monthold Fisher rats, and it is described by several authors (28-30). PC Cl 3 cells were grown in F12 medium (Sigma, St Louis, MO, USA) supplemented with 5\% calf serum (Flow Laboratories, Costa Mesa, CA, USA) and a mix of six hormones: TSH, somatostatin, insulin, growth hormone, glycyl-hystidyl-lysine and transferrin (Sigma). Experiments with PC Cl 3 cells were performed by growing cells to semiconfluence and subsequently starving them in serum-free medium supplemented with $0.5 \%$ BSA for three days. Bovine TSH (Sigma), forskolin (Sigma), TPA (Sigma), insulin (Sigma), 5,6dichloro-1- $\beta$-D-ribofuranosylbenzimidazole (DRB) (Sigma) and cycloheximide (Sigma), were diluted at the concentrations indicated in the Results section in serum-free F12 medium supplemented with $1 \%$ calf serum or $0.5 \%$ BSA. PC Cl 3 cells were analyzed for DNA content by flow cytometry. Cells were collected and washed in PBS. DNA was stained with propidium iodide $(50 \mu \mathrm{g} / \mathrm{ml})$ and analyzed with a FACScan flow cytometer (Becton Dickinson, San Jose, CA, USA) interfaced with a Helwett Packard computer (Palo Alto, CA, USA). Cell cycle data analysis was performed by the CELL-FIT program (Becton Dickinson).

\section{In vitro studies in proylthiouracil-fed and iodide-refed rats}

Thirty 8-week-old Fisher rats were fed with rat chow having a low iodide content. The goitrogen agent, propylthiouracil (PTU) was added to the drinking water at a concentration of $2 \mathrm{mg} / \mathrm{ml}$. Thirty 8-week-old Fisher rats fed with normal chow were used as controls. After $1,3,8$, and 16 days, the rats were anesthetized with ether, blood samples were taken from the jugular vein and rats were killed. TSH, tri-iodothyronine $\left(\mathrm{T}_{3}\right)$ and thyroxine $\left(\mathrm{T}_{4}\right)$ were evaluated by radioimmunoassay using a rat-specific kit (Amity Amersham, Little Chalfont, Bucks, UK). Thyroid glands were removed and divided into two equal representative parts: one was weighed and subsequently frozen in liquid nitrogen until RNA extraction was performed, the other was fixed in $4 \%$ paraformaldehyde for $15 \mathrm{~h}$ at $4{ }^{\circ} \mathrm{C}$, embedded in paraffin and then processed for immunoperoxidase staining.

To study the effects of iodide on thyroid hyperplasia in vivo, twenty 8-week-old Fisher rats were fed 
with rat chow having a low iodide content. PTU, at a concentration of $2 \mathrm{mg} / \mathrm{ml}$, was added to the water for 16 days. Subsequently, PTU treatment was suspended and rats were given iodide in the water at a concentration of $3 \mu \mathrm{g} / \mathrm{ml}$. As controls, 20 rats drinking normal water were used. After 1, 5 and 10 days, the rats were anesthetized with ether, blood was taken and animals were killed. Thyroid glands were removed and divided into two equal representative parts: one was immediately frozen in liquid nitrogen until RNA extraction was performed, the other was fixed in $4 \%$ paraformaldehyde for $15 \mathrm{~h}$ at $4^{\circ} \mathrm{C}$, embedded in paraffin and then processed for immunoperoxidase staining.

\section{RNA extraction and Northern blotting hybridization}

Total cellular RNA was isolated from cultured cell lines as described previously (31). RNA was extracted from frozen specimens by the CsCl cushion method (32) with minor modifications. Northern blots were performed essentially as described (33) using nylon Hybond-N membranes (Amersham Inc.), according to the instructions provided by the manufacturer. All cDNA probes were radiolabeled with a random primed synthesis kit (Multi-Prime, Amersham Inc.). Hybridization reactions were performed at $42{ }^{\circ} \mathrm{C}$, in $50 \%$ formamide, $5 \%$ Denhardt's solution, $5 \times$ SSPE, $0.2 \%$ SDS and $100 \mu \mathrm{g} / \mathrm{ml}$ denatured sonicated salmon sperm DNA, with $2 \times 10^{6}$ c.p.m. $/ \mathrm{ml}$ hybridization solution. Filters were washed at $60^{\circ} \mathrm{C}$ twice in $2 \times \mathrm{SSC}, 0.2 \%$ SDS for $30 \mathrm{~min}$ and subsequently, for the stringent washes, twice for $30 \mathrm{~min}$ each in $0.2 \times \mathrm{SSC}, 0.1 \%$ SDS. Filters were airdried and exposed to autoradiographic film for 4 days in the case of thymosin $\beta 10$ probe. The thymosin $\beta 10$ probe and the glyceraldehyde-3-phosphate dehydrogenase (GAPDH) plasmid used in this study have been described elsewhere (25).

The homology between rat thymosin $\beta 4$ and thymosin $\beta 10$ nucleotide sequences in the region spanning the probe used is $61 \%$. In order to be certain that the human thymosin $\beta 10$ probe used discriminated between thymosin $\beta 4$ and thymosin $\beta 10$, we amplified either rat thymosin $\beta 4$ or thymosin $\beta 10$ from RNA extracted from $\mathrm{PC} C l \quad 3$ cells using the following primers: 5'-TCGTCTCTCCTTGTTCG-3' and 5'-CAATGCTCGTGGAATGT-3' (for rat thymosin $\beta 4$ ); 5'-GATCT-CGGGCTCGGAACGAG-3', 5'-TTAGGAAATTTCACCGC-3' (for rat thymosin $\beta 10$ ).

Amplified DNA fragments were cloned into pCR II vectors and sequenced to determine their identity. Subsequently, 0.01, 0.1 and $1 \mathrm{ng}$ thymosin $\beta 4$ - or thymosin $\beta 10$-specific PCR products, respectively, were loaded onto a $2 \%$ agarose gel, transferred to a nylon membrane and hybridized with the human thymosin $\beta 10$ probe used in this study, in the same experimental conditions as described for Northern blot experiments.
Under these conditions the thymosin $\beta 10$ probe used in this study recognized the rat thymosin $\beta 10$ but not the rat thymosin $\beta 4$.

\section{Nuclear RNA isolation}

The run-on in vitro assay was used on nuclei isolated from the rat $\mathrm{PC} \mathrm{Cl} 3$ thyrocytes. $\mathrm{PC} \mathrm{Cl} 3$ cells were grown to semiconfluence and starved for $48 \mathrm{~h}$ in F12 medium supplemented with $0.5 \%$ BSA. Exogenous TSH was added to starved $\mathrm{PC} \mathrm{Cl} 3$ cells at a dose of $1 \mathrm{mU} / \mathrm{ml}$ in F12 with $0.5 \%$ BSA. After $24 \mathrm{~h}$ stimulation with TSH, approximately $3 \times 10^{7}$ cells were collected by centrifugation at 2000 r.p.m. for $5 \mathrm{~min}$, resuspended in lysis buffer $(10 \mathrm{mmol} / \mathrm{l}$ Tris-HCl pH 7.4, $10 \mathrm{mmol} / \mathrm{l} \mathrm{NaCl}$, $3 \mathrm{mmol} / \mathrm{l} \mathrm{MgCl}_{2}, 0.5 \% \mathrm{NP} 40$ ) and incubated in ice for $20 \mathrm{~min}$. Nuclei were isolated by centrifugation at 1600 r.p.m., counted and stored in storage buffer (50 mmol/l Tris-HCl pH 8.3, 40\% (v/v) glycerol, $5 \mathrm{mmol} / \mathrm{l} \mathrm{MgCl}_{2}$ and $0.1 \mathrm{mmol} / \mathrm{l} \mathrm{EDTA}$ ) at a concentration of $10^{8}$ nuclei $/ \mathrm{ml}$ in liquid nitrogen. In vitro transcription was performed using $5 \times 10^{6}$ nuclei in a reaction buffer containing $10 \mathrm{mmol} / \mathrm{l}$ Tris $-\mathrm{HCl}$ $\mathrm{pH} 8.0,300 \mathrm{mmol} / \mathrm{l} \mathrm{KCl}$ and $5 \mathrm{mmol} / \mathrm{l} \mathrm{MgCl}_{2}$, and $150 \mu \mathrm{Ci}\left[{ }^{32} \mathrm{P}\right] \mathrm{UTP}$ incubated for $60 \mathrm{~min}$ at $28^{\circ} \mathrm{C}$. Nuclear RNA was prepared as previously described (34).

\section{Hybridization to immobilized plasmid DNA}

Fifteen micrograms of the plasmid pGEM4Z (Promega Inc., Madison, WI, USA) and of the plasmids carrying human thymosin $\beta 10$ and rRNA 18S were linearized, denatured with $2 \mathrm{~mol} / \mathrm{l} \mathrm{NaOH}$, neutralized and applied to slot blot apparatus. Nylon filters (Hybond-N, Amersham Inc.) were subsequently fixed by UV irradiation. Hybridization reactions were performed at $42{ }^{\circ} \mathrm{C}$, in $50 \%$ formamide, $5 \%$ Denhardt's solution, $50 \mathrm{mmol} / \mathrm{l} \mathrm{Na}$ phosphate pH 7.0, $5 \times \mathrm{SSC}, 0.1 \%$ SDS and $100 \mu \mathrm{g} / \mathrm{ml}$ denatured sonicated salmon sperm DNA, and $2.5 \mu \mathrm{g} / \mathrm{ml}$ pGEM $4 Z$ plasmid, with $5 \times 10^{6}$ c.p.m./ml hybridization solution. Filters were washed at room temperature in $2 \times$ SSC, $0.2 \%$ SDS twice for $30 \mathrm{~min}$ and subsequently, for the stringent washes, twice for $30 \mathrm{~min}$ each in $2 \times \mathrm{SSC}, 0.1 \% \mathrm{SDS}$ at $60^{\circ} \mathrm{C}$, and for $30 \mathrm{~min}$ at $37^{\circ} \mathrm{C}$ in $10 \mu \mathrm{g} / \mathrm{ml}$ RNAse in $2 \times \mathrm{SSC}$. Filters were air-dried and exposed to autoradiographic film for 15 days in the case of pGEM $4 \mathrm{Z}$ and of thymosin $\beta 10$ probe, and for 1 day in the case of the rRNA $18 \mathrm{~S}$ probe.

\section{Immunoperoxidase staining and proliferation index in experimental goiters}

Immunohistochemistry was performed using purified anti-proliferating cell nuclear antigen (PCNA) antibodies (DAKO, Glostrup, DK) at a concentration of $1 \mu \mathrm{g}$ / $\mathrm{ml}$. Control reactions were performed using control normal rabbit immunoglobulin $\mathrm{G}(\mathrm{IgG})$ at concentrations of $1 \mu \mathrm{g} / \mathrm{ml}$. Incubation with anti-rabbit IgG and 
avidin-biotin-peroxidase complex was carried out according to the supplier's conditions (Vectastain, Burlingame, CA, USA) followed by counterstain with Harris' hematoxylin. To determine the labeling index after PTU and PTU followed by iodide treatments, the number of follicular cell nuclei stained by PCNA antibodies and the total number of nuclei were calculated. In each of 2 separate experiments, nuclei were counted in 5 representative fields from 2 different sections. A minimum of 200 cells per field were counted. The percentage of nuclei that were labeled, the labeling index, was determined for each treatment. The averages with standard errors are reported in Fig. 2.

\section{Results}

\section{Analysis of thymosin $\beta 10$ mRNA expression in human thyroid goiters}

To investigate the role of thymosin $\beta 10$ in the development of thyroid goiters, we analyzed 5 human goiters for thymosin $\beta 10$ expression by Northern blot hybridization. The results are reported in Fig. 1. Normal thyroid tissue expressed low levels of thymosin $\beta 10$ transcript of $0.9 \mathrm{~kb}$ (Fig. 1). An increase of approximately 2 - to 5 -fold in the mRNA expression of thymosin $\beta 10$ was observed in all $(5 / 5)$ goiters analyzed, as measured by autoradiographic film scanning, indicating that over-expression of thymosin $\beta 10$ is a frequent event in human thyroid goiters. Filters were normalized by hybridization with GAPDH.

\section{Effect of PTU and iodide treatment on rat thyroid gland in vivo and on thymosin $\beta 10$ mRNA expression}

To investigate the role of thymosin $\beta 10$ during thyroid goiter development, we used PTU-fed rats as an in vivo

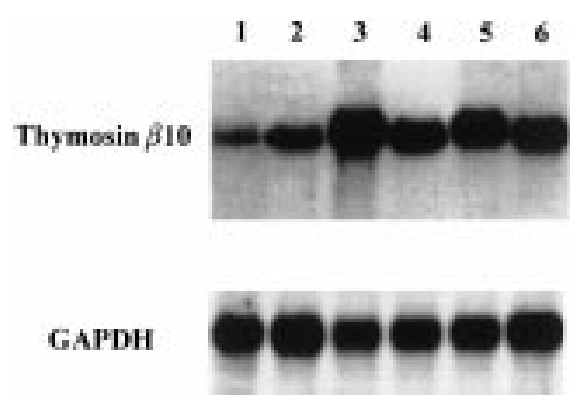

Figure 1 Analysis of thymosin $\beta 10$ gene expression in human thyroid goiters by Northern blot. Twenty micrograms total RNA derived from normal thyroid (lane 1) and goiters from patients with Graves' disease (lanes 2-6) were loaded in each lane. The bottom portion of the figure shows hybridization with GAPDH to ensure RNA uniform loading and integrity. model of thyroid goitrogenesis. In PTU-fed rats the serum levels of TSH significantly increased (day 0, $0.70 \pm 0.12 \mathrm{ng} / \mathrm{ml}$; day $16,5.6 \pm 0.11 \mathrm{ng} / \mathrm{ml}$ ), and were accompanied by a marked enlargement of the thyroid glands, as demonstrated by the increase in the weight of the glands (day 0, $16.7 \pm 1.8 \mathrm{mg}$; day 16 , $48.2 \pm 3.6 \mathrm{mg}$ ), and a marked reduction in the levels of the thyroid hormones $\mathrm{T}_{3}$ (day $0,0.7 \mathrm{ng} / \mathrm{ml}$; day 16 , $0.2 \mathrm{ng} / \mathrm{ml}$ ) and $\mathrm{T}_{4}$ (day $0,5.1 \mathrm{mg} / \mathrm{dl}$; day $16,1.1 \mathrm{mg} /$ dl). During the first weeks of goitrogen administration, there was a rapid change in the morphology of the gland: thyroglobulin was rapidly readsorbed, and this was accompanied by a corresponding decrease in the follicular lumen, since the epithelial cell compartment increased steadily and a marked increase in vascularity occurred (data not shown). To assess the extension and the timing of cell proliferation during the development of thyroid hyperplasia in PTU-fed rats, thyroids were analyzed by hematoxylin-eosine staining and by immunohistochemistry with anti-PCNA antibodies, which stain proliferating cells. Immunohistochemical analysis with anti-PCNA antibodies showed that a proliferation of thyroid follicular cells started from day 5 and peaked between days 8 and 16. The labeling index was calculated as described in Materials and methods and was expressed as a percentage of PCNApositive cells compared with total cell number. The results are plotted in Fig. 2. As expected, follicular cells in the normal thyroid gland showed no staining for PCNA whereas about $7 \%$ and $13 \%$ of thyrocytes stained for PCNA after 8 and 16 days of treatment respectively.

Iodide refeeding to goitrous rats determined a marked involution of thyroid hyperplasia (5). In iodide refed rats, serum levels of TSH remained high for $1-5$ days and decreased steadily after 10 days of treatment (day $0,6.6 \pm 0.15 \mathrm{ng} / \mathrm{ml}$; day $10,1.2 \pm 0.16 \mathrm{ng} / \mathrm{ml}$ ). The decrease in the TSH levels was accompanied by a dramatic reduction in the weight of the thyroid gland. The serum values of the thyroid hormones $\mathrm{T}_{3}$ and $\mathrm{T}_{4}$ returned to normal $(0.7 \mathrm{ng} / \mathrm{ml}$ and $4.7 \mathrm{mg} / \mathrm{dl}$ respectively) on day 10 of iodide refeeding.

Thyroid glands of control rats expressed almost undetectable levels of thymosin $\beta 10$ (Fig. 3, first lane) mRNA. Thymosin $\beta 10$ mRNA expression started to increase on day 3 of PTU treatment with a peak at days 8-16 (Fig. 3, lanes 2-4). The kinetics of thymosin $\beta 10$ up-regulation induced by increased levels of TSH in PTU-fed rats perfectly overlapped the timing of PCNAlabeling of thyroid follicular cell nuclei, suggesting that thymosin $\beta 10$ may play a pivotal role in the proliferation of TSH-stimulated thyroid cells.

We also investigated the effects of refeeding goitrous rats with iodide on the mRNA expression of thymosin $\beta 10$. Upon iodine refeeding to 16 -day PTU-treated rats, thymosin $\beta 10$ mRNA expression gradually decreased from day 1 to return to basal levels by day 10 (Fig. 3, lanes 5,6 ), in parallel with the decreased proliferation 


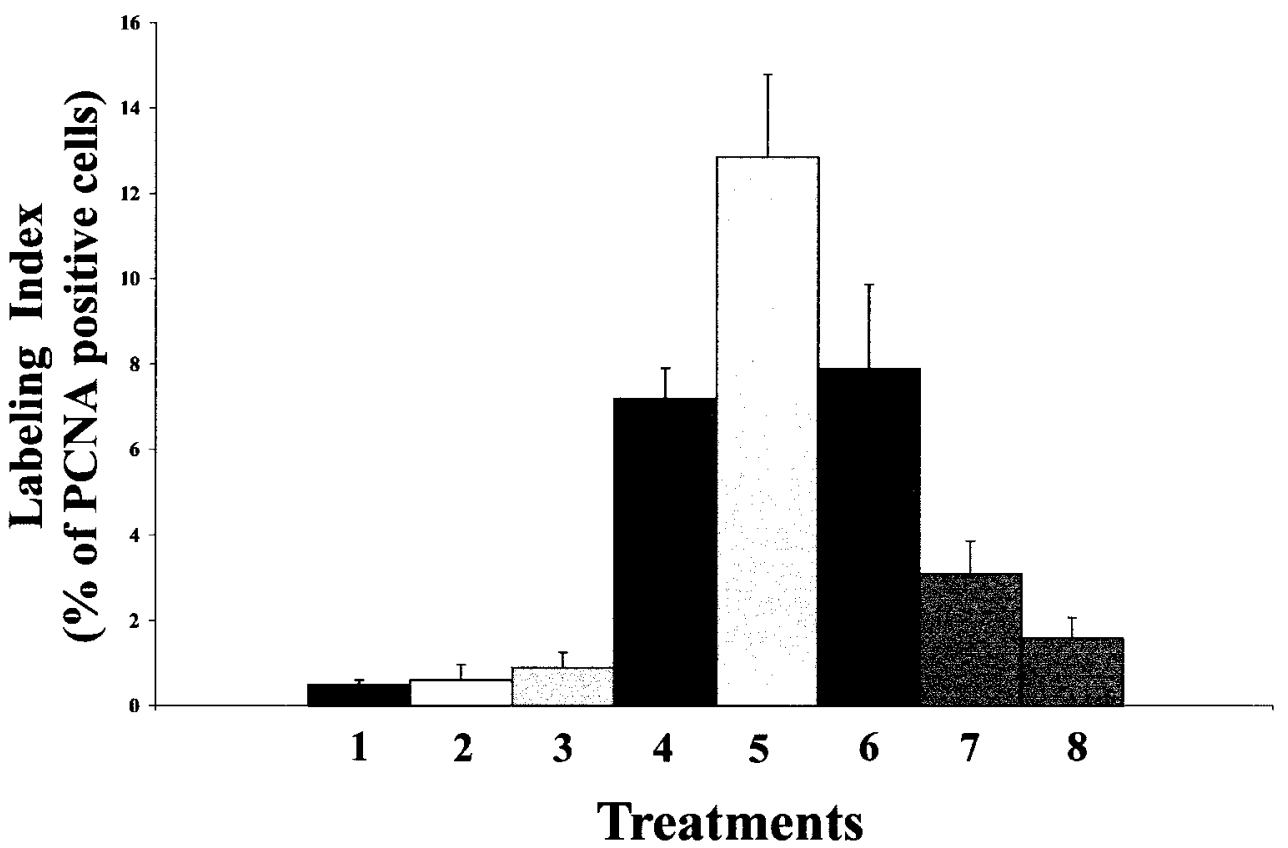

Figure 2 Comparison of the labeling index in follicular cells in the thyroid glands of rats treated with PTU or with PTU followed by iodide. The labeling index for each treatment was calculated as described. Paraffin sections from thyroids derived from normal rats (bar 1), from rats treated with PTU for $1,3,8$ and 16 days (bars 2, 3, 4 and 5 respectively) or with PTU for 16 days followed by iodide administration for 1,5 and 10 days (bars 6,7 and 8 respectively) were used.

of thyrocytes (Fig. 2) and the consequent regression of thyroid hyperplasia induced by iodide.

\section{The activation of the PKA-dependent pathway up-regulates mRNA expression of thymosin $\beta 10$ in cultured thyrocytes}

Our in vivo data suggested that the expression of thymosin $\beta 10$ may be associated with the proliferation of thyroid follicular cells. Since TSH represents the major physiological modulator of thyroid growth and

$\begin{array}{llllll}1 & 2 & 3 & 4 & 5 & 6\end{array}$

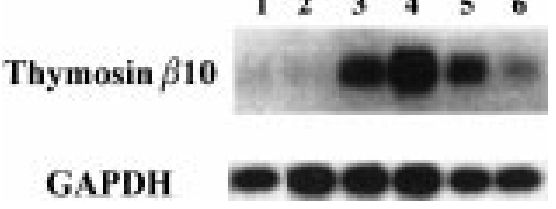

Figure 3 Analysis of the mRNA expression of thymosin $\beta 10$ in the thyroid gland of PTU-treated and iodide-refed goitrogenous rats, by Northern blot. Lane 1: normal thyroid glands from control rats; lanes 2-4: thyroid glands from rats treated with PTU for 3,8 and 16 days respectively; lanes 5 and 6 : thyroid glands from rats treated with PTU for 16 days and subsequently refed with iodide for 1 and 10 days respectively. Twenty micrograms total RNA were loaded in each lane. The bottom portion of the figure shows hybridization with GAPDH to ensure RNA uniform loading and integrity. The ratios of thymosin $\beta 10$ mRNA to $18 \mathrm{~S}$ RNA in PTU-fed rats compared with control rats (1 at day 0) were 1.8-, 6.4-, and 7.1 -fold respectively on days 3,8 and 16 . function, we first investigated the molecular effects of TSH on thymosin $\beta 10$ mRNA expression, using the rat thyroid cell line PC Cl 3 as an in vitro model. PC Cl 3 cells are cultured rat thyroid cells which represent a suitable model to investigate the relationship between cell growth and differentiation, since they express all the molecular differentiative thyroid markers such as thyroglobulin, TSH receptor and thyroperoxidase (27-29) and are able to take up iodide from the culture medium.

RNA prepared from untreated cultures of $\mathrm{PC} \mathrm{Cl} 3$ cells contains small amounts of a single thymosin $\beta 10$ transcript of $0.9 \mathrm{~kb}$. Treatment of cells with $1 \mathrm{mU} / \mathrm{ml}$ TSH resulted in a rapid increase in the level of thymosin $\beta 10$ mRNA, which peaked at $3-6 \mathrm{~h}$ and remained elevated until $48 \mathrm{~h}$ (Fig. 4). The increased expression of thymosin $\beta 10$ mRNA induced by TSH was dosedependent (cells were treated for $3 \mathrm{~h}$ with $0.01,0.1$ and $1 \mathrm{mU} / \mathrm{ml} \mathrm{TSH}$ ) as shown in Fig. 4. In a first set of experiments, we added TSH to the culture medium in the absence of serum to avoid possible interference of serum on TSH effects. However, similar results were obtained when TSH was administered in the presence of $1 \%$ calf serum (data not shown).

TSH modulates thyroid functions by binding to a high affinity receptor of the 'seven-spanned transmembrane domains' (TSHR) on the thyrocyte cell surface, whose activation increases intracellular cAMP levels, which in turn activate PKA as well as phosphatidyl inositol turnover in thyroid cells (6). To investigate whether the TSH-regulated induction of thymosin 
$\mathbf{A}$

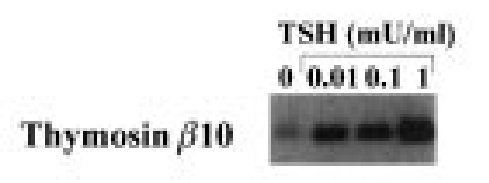

GAPDH

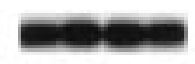

C

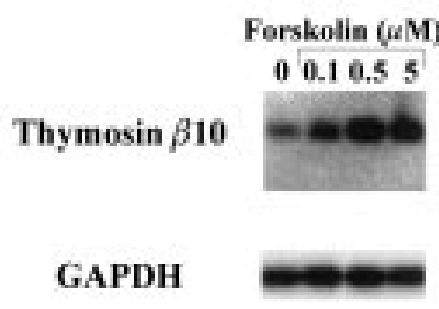

B

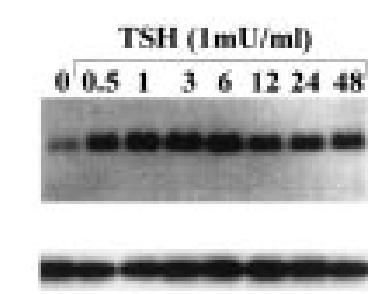

D

Forskolin ( $5 u \mathrm{M})$
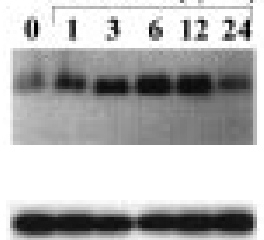

Figure 4 Regulation of thymosin $\beta 10$ mRNA expression by the PKA-dependent pathway in the cultured rat thyroid cell line, $\mathrm{PC} \mathrm{Cl} 3$. Dose-dependent and time-course analyses of TSH regulation of thymosin $\beta 10$ mRNA expression in rat thyroid cells are shown in the upper panels. (A) The levels of thymosin $\beta 10$ mRNA are strongly induced by treatment of 3 day-starved PC cells with increasing amounts of TSH $(0.01,0.1$, and $1 \mathrm{mU} / \mathrm{ml})$ for $3 \mathrm{~h}$ (lane 1, untreated PC cells; lanes 2-4, treatment with the indicated concentration of TSH). (B) Thymosin $\beta 10$ steady-state mRNA levels are markedly increased by treatment of PC cells with $1 \mathrm{mU} / \mathrm{ml} \mathrm{TSH}$ (lane 1 , untreated PC cells; lanes 2-7, TSH treatment for the indicated time (h)). Dose-dependent and time-course analyses of forskolin regulation of thymosin $\beta 10$ mRNA expression in rat thyroid cells are shown in the lower panels. (C) The levels of thymosin $\beta 10$ mRNA are strongly induced by treatment of 3 day-starved PC cells with increasing amounts of the PKA activator, forskolin $(0.1,0.5$, and $5 \mu \mathrm{mol} / \mathrm{l}$ ) for $3 \mathrm{~h}$ (lane 1, untreated PC cells; lanes 2-4, treatment with the indicated concentration of forskolin). (D) Thymosin $\beta 10$ steady-state mRNA levels are markedly increased by treatment with forskolin $(5 \mu \mathrm{mol} / \mathrm{l})$ with a peak at 3-6h (lane 1, untreated PC cells; lanes 2-4, forskolin treatment for the indicated time $(h))$. The bottom portions of the figure show hybridization with GAPDH to ensure RNA uniform loading and integrity. $\beta 10$ expression could be mediated by PKA, we evaluated whether thymosin $\beta 10$ mRNA expression was induced by treatment with forskolin, which increases the intracellular level of cAMP. As shown in Fig. 4, treatment of $\mathrm{PC} \mathrm{Cl} 3$ cells with forskolin stimulated thymosin $\beta 10$ mRNA expression in a dose-dependent manner. Time-course experiments (Fig. 4) at a dose of $5 \mu \mathrm{g} / \mathrm{ml}$ showed that the kinetics of induction of thymosin $\beta 10$ mRNA induced by forskolin was similar to TSH, suggesting cAMP mediation in the induction of thymosin $\beta 10$ mRNA expression exerted by TSH.

To correlate the induction of thymosin $\beta 10$ mRNA by TSH and forskolin in PC $\mathrm{Cl} 3$ cells with the extent of cell proliferation, we have also performed a flow cytometry analysis of TSH- or forskolin-stimulated PC $\mathrm{Cl} 3$ cells. Cells were starved in medium containing $0.5 \% \mathrm{BSA}$ and subsequently they were stimulated with $1 \mathrm{mU} / \mathrm{ml}$ TSH and with $5 \mu \mathrm{g} / \mathrm{ml}$ forskolin. At different times after stimulation, cells were collected

Table 1 Percentage of S phase PC Cl 3 cells. Cells were starved on $0.5 \%$ BSA for 3 days and subsequently treated with TSH $(1 \mathrm{mU} / \mathrm{ml})$, forskolin $(5 \mu \mathrm{g} / \mathrm{ml})$ and insulin $(10 \mu \mathrm{g} / \mathrm{ml})$ for the indicated times in the presence of $1 \%$ calf serum.

\begin{tabular}{lrrrr}
\hline & \multicolumn{4}{c}{ Time $(\mathrm{h})$} \\
\cline { 2 - 5 } Treatment & 0 & 12 & 24 & 48 \\
\hline TSH & 6 & 11 & 28 & 14 \\
Forskolin & 6 & 8 & 19 & 10 \\
Insulin & 6 & 6 & 21 & 8 \\
\hline
\end{tabular}

and analyzed by flow cytometry. Results are reported in Table 1.

\section{The activation of different mitogenic pathways up-regulates mRNA expression of thymosin $\beta 10$ in cultured thyrocytes}

The activation of the PKC pathway by phorbol esters (TPA) has been shown to be mitogenic for cultured thyroid cells in vitro; however, in contrast to TSH, TPA also exerts dedifferentiating effects on thyroid cells (6). Therefore, to determine whether thymosin $\beta 10$ mRNA expression was also regulated through pathways other than the TSHR/PKA cascade, we performed Northern blot analysis of TPA-stimulated PC Cl 3 cells. Analysis of TPA-stimulated thyrocytes showed that the steady-state level of thymosin $\beta 10$ transcript increased in response to TPA stimulation in a dose-dependent manner, with maximal stimulation occurring at a concentration of $10 \mathrm{ng} / \mathrm{ml}$ (Fig. 5A). Furthermore, time-course analysis of TPA-induced thymosin $\beta 10$ stimulation showed that thymosin $\beta 10$ transcript began to accumulate as early as $1 \mathrm{~h}$ and peaked after $3-6 \mathrm{~h}$ from the beginning of the treatment (Fig. 5B). These results demonstrated that thymosin $\beta 10 \mathrm{mRNA}$ expression was regulated by the activation of the PKC transduction pathway in a time- and dose-dependent manner.

Activation of membrane receptors with tyrosine kinase activity (RTK) is a common event in growth factor-stimulated, proliferating cells (34). In the case of thyroid cells, insulin has been shown to be mitogenic for cultured thyrocytes, possibly by interacting with 


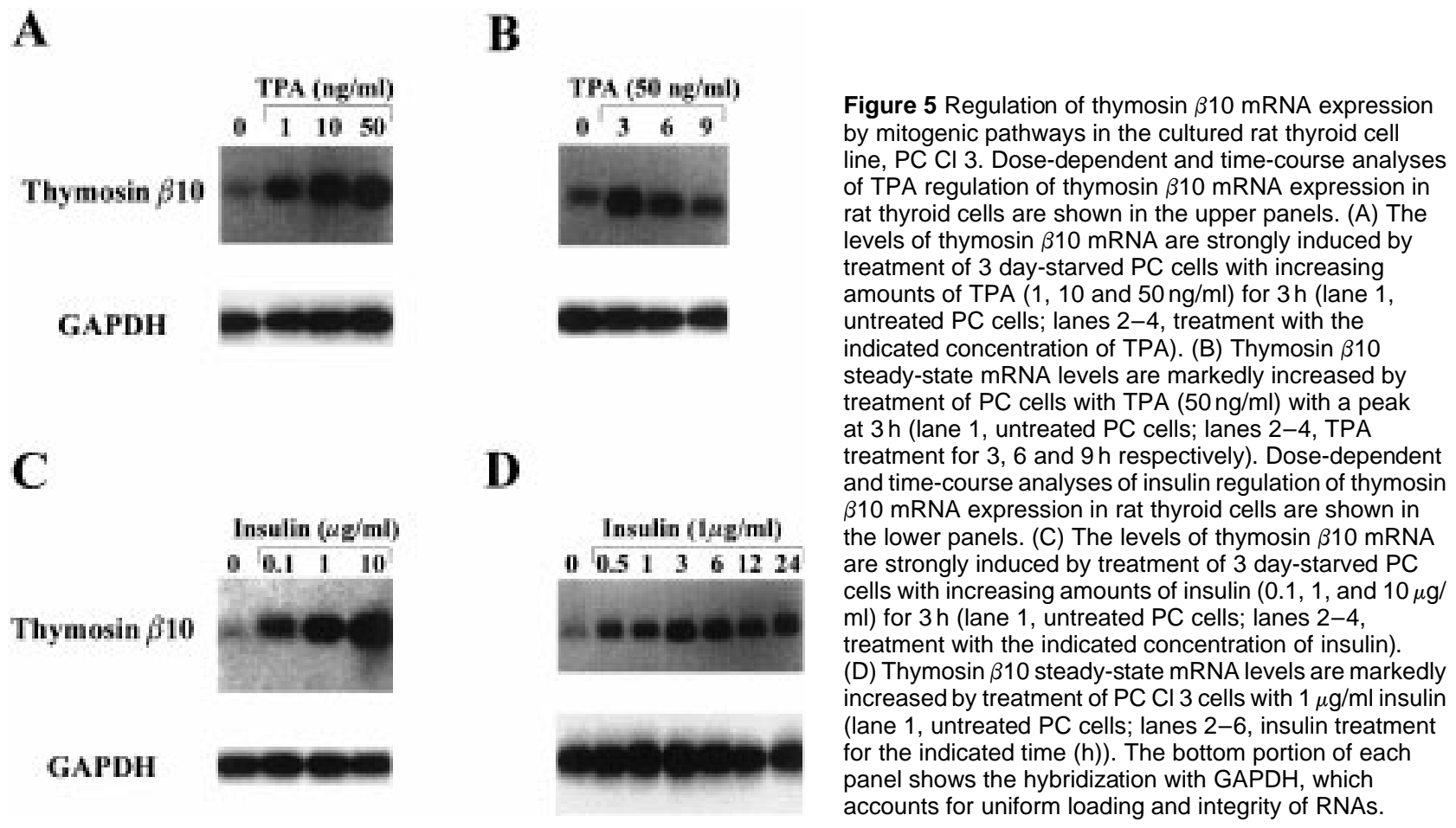

the insulin-like growth factor (IGF)-I receptor, thus mimicking the mitogenic effects of IGF-I (6). To investigate the role of RTK activation on the expression of thymosin $\beta 10$, we determined the effects exerted by insulin on thymosin $\beta 10$ mRNA expression in cultured thyroid cells. As shown in Fig. 5C and D, the level of the steady-state of thymosin $\beta 10$ transcript was dramatically augmented in response to insulin stimulation in a dose-dependent manner. Insulin treatment of $\mathrm{PC} \mathrm{Cl} 3$ cells induced the accumulation of the thymosin $\beta 10$ transcript as early as $1 \mathrm{~h}$, with a peak occurring at $1-3 \mathrm{~h}$ after the beginning of the treatment, demonstrating that thymosin $\beta 10$ expression may be modulated by the activation of the insulin pathway.

To correlate the induction of thymosin $\beta 10$ mRNA by insulin in $\mathrm{PC} \mathrm{Cl} 3$ cells with the extent of cell proliferation, we have also performed a flow cytometry analysis of insulin-stimulated PC $\mathrm{Cl} 3$ cells. Cells were starved in medium containing $0.5 \%$ BSA and subsequently stimulated with $10 \mu \mathrm{g} / \mathrm{ml}$ insulin. At different times after stimulation, cells were collected and analyzed by flow cytometry. Results are reported in Table 1.

\section{Effects of RNA synthesis inhibitors and protein synthesis inhibitors on TSH-induced regulation of thymosin $\beta 10 \mathrm{mRNA}$}

TSH represents the major modulator of thyroid growth, differentiation and function (6). To further study the molecular mechanisms whereby thymosin $\beta 10$ mRNA expression is regulated by the PKA pathway, we studied the effects of the RNA polymerase inhibitor DRB (at a dose of $25 \mu \mathrm{g} / \mathrm{ml}$ ) on the transcription of thymosin $\beta 10$ mRNA exerted by TSH (Fig. 6A). In the presence of $\mathrm{DRB}$, the TSH-induced increase in the steady-state levels of thymosin $\beta 10$ (Fig. 6A) was strongly reduced, suggesting that TSH stimulation of thymosin $\beta 10$ may occur, at least in part, at the transcriptional level. The rapid increase of thymosin $\beta 10$ mRNA induced by TSH in thyrocytes suggests a rapid induction of thymosin $\beta 10$ mRNA similar to that of early genes such as $c$-fos. Further to characterize the mechanism for TSH upregulation of thymosin $\beta 10$, we examined the effect of the protein synthesis inhibitor cycloheximide (Fig. 6B). In PC $\mathrm{Cl} 3$ cells, the increase in thymosin $\beta 10 \mathrm{mRNA}$ after 1 or $3 \mathrm{~h}$ of treatment with TSH was not substantially modified by cycloheximide $(5 \mu \mathrm{g} / \mathrm{ml})$ pretreatment of PC Cl 3 cells, suggesting that protein synthesis may not be necessary for thymosin $\beta 10$ gene transcription. Conversely, control experiments using the vascular endothelial growth factor (VEGF) probe which is superinduced by TSH in the presence of cycloheximide, confirmed that cycloheximide $(5 \mu \mathrm{g} / \mathrm{ml})$ had no gross effect on thymosin $\beta 10$ mRNA expression (data not shown).

\section{Transcriptional analysis of thymosin $\beta 10$ in cultured thyrocytes}

The effects exerted by the RNA polymerase inhibitor DRB on the steady-state level of thymosin $\beta 10$ mRNA level induced by TSH suggest that TSH is able to stimulate the transcriptional rate of the thymosin $\beta 10$ 


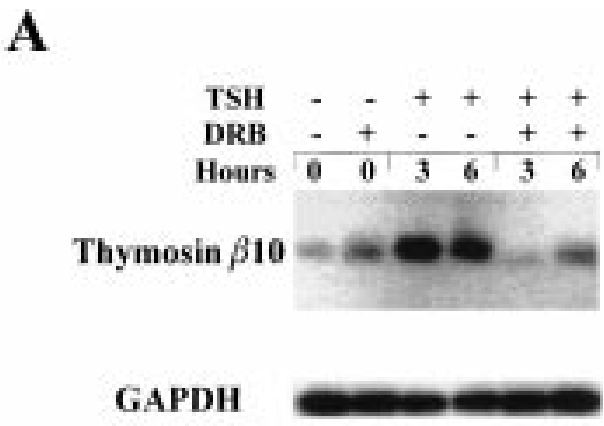

B

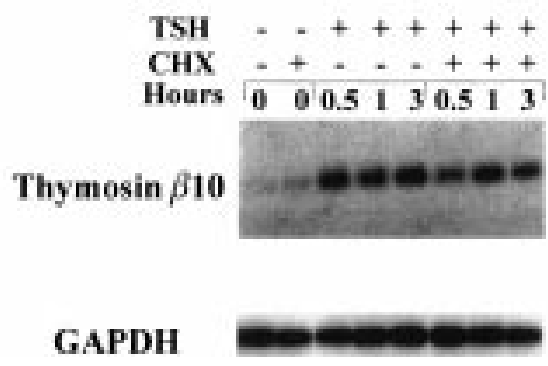

Figure 6 The effect of RNA polymerase and protein synthesis inhibitor on thymosin $\beta 10$ mRNA expression induced by TSH. (A) DRB on TSH induction of thymosin $\beta 10$ mRNA expression in $\mathrm{PC} \mathrm{Cl} 3$ thyroid cells. PC Cl 3 cells were treated with $1 \mathrm{mU} / \mathrm{ml} \mathrm{TSH}$ for 1 and $3 \mathrm{~h}$ in the presence $(+)$ and absence $(-)$ of DRB $(25 \mu \mathrm{g} / \mathrm{ml})$. Total RNA (20 $\mu \mathrm{g} /$ lane) was subjected to Northern blot analysis using thymosin $\beta 10$ as probe. Lane 1, untreated PC cells; lane 2, PC cells treated with $25 \mu \mathrm{g} / \mathrm{ml}$ DRB; lanes 3 and 4: TSH treatment for the indicated time in the absence of DRB; lanes 5 and 6 : TSH treatment for the indicated time in the presence of $25 \mu \mathrm{g} / \mathrm{ml}$ DRB. The bottom portion of the figure shows the ethidium bromide staining of the gel. (B) The effect of cycloheximide (CHX) on TSH induction of thymosin $\beta 10$ mRNA expression in $\mathrm{PC} \mathrm{Cl} 3$ thyroid cells. PC Cl 3 cells were treated with $1 \mathrm{mU} / \mathrm{ml} \mathrm{TSH}$ for $0.5,1$ and $3 \mathrm{~h}$ in the presence $(+)$ or absence $(-)$ of $\mathrm{CHX}(5 \mu \mathrm{g} / \mathrm{ml})$. Total RNA (20 $\mu \mathrm{g} / \mathrm{lane})$ was subjected to Northern blot analysis using thymosin $\beta 10$ as probe. Lane 1, untreated PC cells; lane 2, PC cells treated with $5 \mu \mathrm{g} / \mathrm{ml} \mathrm{CHX}$; lanes 3-5: TSH treatment for 0.5 , 1 and $3 \mathrm{~h}$ in the absence of CHX; lanes 6-8: TSH treatment for 0.5 , 1 and $3 \mathrm{~h}$ in the presence of $5 \mu \mathrm{g} / \mathrm{ml} \mathrm{CHX}$. The bottom portion of the figure shows hybridization with GAPDH to ensure RNA uniform loading and integrity.

gene. To determine whether TSH exerts a regulatory control on the transcriptional rate of thymosin $\beta 10$, we performed run-on transcription assays on nuclei isolated from cultured rat thyrocytes treated with TSH (Fig. 7). As shown in Fig. 7, PC Cl 3 cells express a basal amount of thymosin $\beta 10$ transcript. However, the transcriptional rate of the thymosin $\beta 10$ gene increased 2 - to 3-fold after TSH treatment, thus confirming that TSH may regulate thymosin $\beta 10$ gene expression by controlling the transcriptional rate. However, since the increase in the transcriptional rate did not account

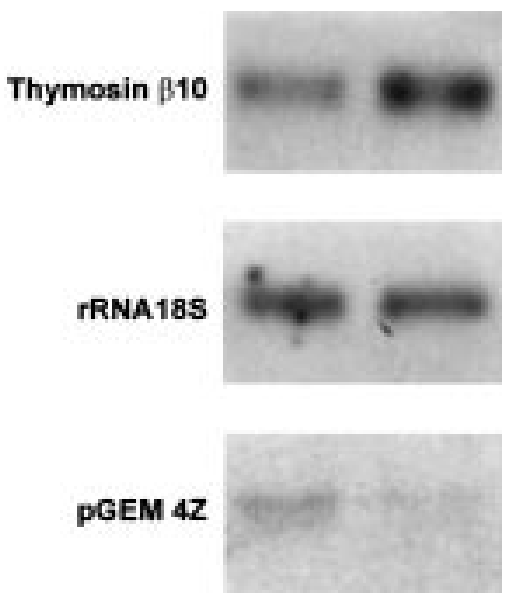

Figure 7 Transcriptional activation of thymosin $\beta 10$ gene after stimulation of thyroid cells by TSH. Plasmids carrying the thymosin $\beta 10$ or rRNA $18 \mathrm{~S}$ inserts bound to nylon filters were hybridized with ${ }^{32} \mathrm{P}$-labeled run-on transcripts from nuclei isolated after $24 \mathrm{~h}$ from the beginning of TSH stimulation of $\mathrm{PC} \mathrm{Cl} 3$ cells. Filters were exposed to autoradiographic film for 15 days in the case of pGEM $4 Z$ and thymosin $\beta 10$ probes, and for $12 \mathrm{~h}$ in the case of rRNA 18S probe. Increased transcription rate induced by TSH in $\mathrm{PC} \mathrm{Cl} 3$ cells was observed in the case of thymosin $\beta 10$ (2- to 3 -fold), whereas no change in the transcription rate of rRNA $18 \mathrm{~S}$ was observed after TSH stimulation.

completely for the increase in the steady-state mRNA level induced by TSH, it is likely that, in addition to a transcriptional control, TSH may modulate thymosin $\beta 10$ mRNA expression through post-transcriptional regulatory mechanisms. Control experiments (using pGEM $4 \mathrm{Z}$ and the plasmid carrying the insert for rRNA $18 \mathrm{~S})$ demonstrated that the increase in the hybridization signal observed in the lane containing the plasmid carrying the thymosin $\beta 10$ cDNA, hybridized with nuclear RNA extracted from TSH-treated cells compared with untreated cells, was not due to an aspecific effect. Altogether, these data suggest that the regulation of the expression of thymosin $\beta 10$ induced by TSH in thyroid cells occurs, at least in part, at the transcriptional level.

\section{Discussion}

In this study we provide evidence that the mRNA expression of thymosin $\beta 10$ is markedly enhanced in human goiters compared with normal thyroid. It has been suggested that increased proliferation of thyrocytes results from the abnormal constitutive activation of the TSH receptor (TSHR) pathway. Theoretically several mechanisms may account for chronic signaling of TSHR in thyroid cells: (i) increased TSH production by pituitary gland; (ii) increased susceptibility of thyrocytes to TSH induced by iodide deficiency as in goitrous patients; (iii) chronic stimulation of TSHR by autoimmune antibodies as in Graves' disease $(1,6)$. To 
investigate the molecular mechanisms regulating thymosin $\beta 10$ in thyroid cells, we made use of a wellknown model of animal goitrogenesis: rats fed with the goitrogen drug, PTU. Propylthiouracil treatment of rats mimicks the constitutive chronic activation of the TSH receptor pathway (1). Upon feeding rats with PTU we observed a marked reduction in the levels of the thyroid hormones $\mathrm{T}_{3}$ and $\mathrm{T}_{4}$ accompanied by a significant increase in the serum TSH level and by a marked enlargement of the thyroid glands. PCNA staining of thyroid sections demonstrated that thyroid follicular cells started to proliferate after 5 days and reached a maximal level of proliferation by days $8-16$. Iodide refeeding to goitrous rats resulted in a steady decrease in the serum values of $\mathrm{T}_{3}$ and $\mathrm{T}_{4}$ and in TSH levels, accompanied by a marked involution of thyroid hyperplasia.

The mRNA expression of thymosin $\beta 10$ in the thyroid gland of PTU-fed rats increased markedly, with a time course overlapping the increase in the TSH level, suggesting that thymosin $\beta 10$ expression may be regulated in vivo by TSH. Furthermore, since the upregulation of thymosin $\beta 10$ preceded the response of thyrocytes to TSH, thymosin $\beta 10$ might play an important role in the hyperplasia induced by PTU. Such a conclusion was supported by the finding that subsequent iodide administration to goitrogenous rats reduced the steady-state levels of thymosin $\beta 10 \mathrm{mRNA}$ in parallel with a marked regression of thyroid hyperplasia and the involution of the thyroid vasculature. All together these findings suggest that thymosin $\beta 10$ expression is regulated - either directly or indirectly by increased serum TSH levels and that increased thymosin $\beta 10$ expression may be associated with the remodeling of the thyroid gland induced by chronic TSH stimulation.

The finding that thymosin $\beta 10$ expression is upregulated in human and experimental thyroid goiters, which are characterized by increased proliferation of thyrocytes and by extensive morphological and functional modifications, suggests that thymosin $\beta 10$ may have a role in the regulation of cellular processes such as cell growth and the cytoskeletal assembly. Thymosin $\beta 10$ may modify the equilibrium between monomeric and polymerized G-actin in proliferating thyrocytes. In fact, although an increase in the free G-actin pool may only be inferred on the basis of enhanced mRNA expression, it is likely that increased expression of thymosin $\beta 10$ in thyroid cells may have a role in the reorganization of the cytoskeleton occurring in TSHstimulated cells (35-37).

In the absence of TSH, thyroid cells undergo drastic morphological and biochemical changes: they become flat, pseudopods and microvilli disappear and actin becomes organized into stress fibers (35-37). As a result of TSH or forskolin stimulation, the actin stress fibers disassemble in parallel with changes in the shape and increased numbers of pseudopods and apical microvilli (35-37). All these modifications appear to have a specific functional significance since it is known that actin cytoskeleton integrity is related to the ability of the cell to secrete thyroid hormone. In this regard, it is conceivable that by decreasing the amount of polymerized actin, thymosin $\beta 10$ may contribute to the disruption of subcortical actin filament which, in turn, is responsible for processes such as vesicle exocytosis and pseudopod formation $(38,39)$.

The mechanisms that regulate thymosin $\beta 10$ mRNA expression have been studied in osteosarcoma and hematopoietic cells $(15,16)$. However, the molecular basis of thymosin $\beta 10$ expression in endocrine tissue is poorly understood. To gain a more detailed knowledge of the regulatory pathways controlling thymosin $\beta 10$ expression in thyroid cells, the cultured rat thyroid cell line $\mathrm{PC} \mathrm{Cl} 3$ was used as an in vitro model system. Here, we show that exogenously added TSH up-regulates thymosin $\beta 10 \mathrm{mRNA}$ expression in a dosedependent manner. TSH-induced up-regulation of thymosin $\beta 10$ mRNA expression occurs, at least in part, at the transcriptional level, as demonstrated by experiments performed with the RNA polymerase inhibitor, DRB. Further confirmation of the transcriptional effects exerted by TSH on the mRNA expression of thymosin $\beta 10$ was obtained by nuclear run-on, which showed a TSH-dependent increase in the transcription rate of the thymosin $\beta 10$ gene. However, timecourse studies and experiments with the protein synthesis inhibitor cycloheximide indicated that TSHinduced thymosin $\beta 10$ mRNA expression did not require protein synthesis, since induction of thymosin $\beta 10$ mRNA by TSH was not modified by cycloheximide treatment, in agreement with the rapid induction of thymosin $\beta 10$ mRNA exerted by TSH.

TSH modulates thyroid functions by activating the cAMP-dependent pathway (6), since activation of the PKA-dependent pathway by the use of forskolin induced a dose- and time-dependent increase in the thymosin $\beta 10$ expression, suggesting that the effects exerted by TSH on thymosin $\beta 10$ mRNA expression were mediated through the cAMP-dependent protein kinase A. Previous work has shown that activation of the cAMP-dependent pathway in neuroblastoma cells down-regulates thymosin $\beta 10$ mRNA expression. Such results are only in apparent contrast with our findings. In fact, in neuroblastoma cells, cAMP acts as a differentiating agent which blocks cell proliferation, whereas in thyroid cells the activation of the PKA pathway by TSH and/or forskolin leads to both proliferation and differentiation.

In the present investigation we also demonstrate that thymosin $\beta 10$ expression in thyroid cells is also regulated by signals, other than TSH, involved in the growth of the thyroid cells, such as phorbol esters and insulin. Activation of the PKC pathway by TPA has been shown to induce thyroid cell proliferation and dedifferentiation (6). Insulin induces thyroid cell proliferation, possibly by mimicking the mitogenic effects of IGF-I through activation of the IGF-I receptor (6). Here, 
we report that both TPA and insulin were able to up-regulate thymosin $\beta 10$ expression in thyroid cells in a dose-dependent manner, suggesting that in thyroid cells the up-regulation of thymosin $\beta 10$ expression is associated with the activation of multiple proliferative pathways. However, it remains to be determined whether thymosin $\beta 10$ expression in thyroid cells is strictly required for growth or, alternatively, if its expression is necessary for other cellular processes that accompany cell proliferation (i.e. cytoskeleton remodeling).

In conclusion, our findings demonstrate that in the thyroid cell, thymosin $\beta 10$ expression is regulated by TSH and other mitogenic pathways such as the PKC and insulin pathways. However, since the biological function of thymosin $\beta 10$ has yet to be defined, further studies are necessary to determine the role of thymosin $\beta 10$ in the thyroid cell during the development of hyperplastic goiters, although the observation that thymosin $\beta 10$ mRNA is over-expressed in human thyroid goiters suggests that it may play a key role in the development of such hyperproliferative disease.

\section{Acknowledgements}

This work was supported by grants from the Associazione Italiana Ricerca sul Cancro (AIRC) to GV and AF. GB, AB, B B and PB are recipients of fellowships from Federazione Italiana per la Ricerca sul Cancro (FIRC).

\section{References}

1 Wilson JD \& Foster DW. The Thyroid. Textbook of Endocrinology, edn 7. Philadelphia, USA: Saunders Company Press, 1989.

2 Wollman SH, Herveg JP, Zeligs JD \& Ericson LE. Blood capillary enlargement during the development of thyroid hyperplasia in the rat. Endocrinology $19781032306-2314$.

3 Wynford-Thomas D, Stringer BMJ \& Williams ED. Goitrogeninduced thyroid growth in the rat: a quantitative morphometric study. Journal of Endocrinology 198294 131-140.

4 Smeds S \& Wollman SH. ${ }^{3} \mathrm{H}$-Thymidine labeling of endothelial cells in thyroid arteries, veins, and lymphatics during thyroid stimulation. Laboratory Investigation 198348 285-291.

5 Rognoni JB, Penel C \& Ducret F. Vascularization and iodide transport down-regulation in rat goitre. Acta Endocrinologica $198410540-48$.

6 Dumont JE, Lamy F, Roger P \& Maenhaut C. Physiological and pathological regulation of thyroid cell proliferation and differentiation by thyrotropin and other factors. Physiological Reviews $199272667-697$.

7 Ridley AJ \& Hall A. The small GTP-binding protein Rho regulates the assembly of focal adhesions and actin stress fibers in response to growth factors. Cells 199270 389-399.

8 Shalloway D \& Shenoy S. Oncoprotein kinases in mitosis. Advances in Cancer Research 199057 184-217.

9 Parson T, Schaller MD, Hildebrand J, Leu T-H, Richardson A \& Otey C. Focal adhesion kinase: structure and signalling. Journal of Cell Science 199418 108-113 (Suppl).

10 Nachmias VT Small actin-binding proteins: the $\beta$-thymosin family. Current Opinion in Cell Biology 19935 56-62.

11 Low TL, Hu SK \& Goldstein AC. Complete amino acid sequence of bovine thymosin $\beta 4$ : a thymic hormone that induces to luminal deoxynucleotidyl transferase activity in thymocyte populations. Proceedings of the National Academy of Sciences of the USA 198178 1162-1166.

12 Gomez-Marquez J, Dosil M, Segade F, Bustelo XR, Pichel JG, Dominguez F \& Freire M. Thymosin-beta 4 gentile. Preliminary characterization and expression in tissues, thymic cells and lymphocytes. Journal of Immunology 1989143 2740-2744.

$13 \mathrm{Yu}$ FX, Lin SC, Morrison-Bogorad M, Atkinson MAL \& Yin H Thymosins $\beta 4$ and $\beta 10$ are both G-actin binding proteins. Journal of Biological Chemistry 1994268 502-509.

14 Safer D \& Nachmias VT. $\beta$-Thymosins as actin binding peptides. BioEssays 199416 473-479.

15 Atkinson MJ, Freeman MW \& Kronenberg HM. Thymosin beta 4 is expressed in ROS 17/2.8 osteosarcoma cells in a regulated manner. Molecular Endocrinology 19904 69-74.

16 Gondo H, Kudo J, White JY, Barr C, Selvanayagam P \& Saunders G. Differential expression of the human thymosin $\beta 4$ gene in lymphocytes, macrophage and granulocytes. Journal of Immunology $19871393840-3848$.

17 Border BG, Lin SC, Griffin ST, Pardue S \& Morrison-Bogorad M. Alterations in actin-binding $\beta$-thymosin expression accompany neuronal differentiation and migration in rat cerebellum. Journal of Neurochemistry $1993612104-2114$.

18 Lin SC \& Morrison-Bogorad MJ. Developmental expression of mRNAs encoding thymosin $\beta_{4}$ and $\beta_{10}$ in rat brain and other tissues. Journal of Molecular Neuroscience 19902 35-44.

19 Lugo DI, Chen SC, Hall AK, Ziai R, Hemstead JL \& Morgan JI. Developmental regulation of $\beta$-thymosins in the rat central nervous system. Journal of Neurochemistry 199156 457-461.

20 Hall AK, Chen SC, Hemstead JL \& Morgan JI. Retinoic acid regulates thymosin $\beta 10$ levels in rat neuroblastoma cells. Journal of Neurochemistry 199156 462-468.

21 Leonard DGB, Ziff EB \& Greene LA. Identification and characterization of mRNAs regulated by nerve growth factor in PC12 cells. Molecular and Cellular Biology 1987 7 3156-3167.

22 Hall AK. Differential expression of thymosin genes in human tumors and in the developing human kidney. International Journal of Cancer $19914672-677$.

23 Weterman MAJ, Van Muijen GNP, Ruiter DJ \& Bloemers HPJ. Thymosin $\beta-10$ expression in melanoma cell lines and melanocytic lesions: a new progression marker for human cutaneous melanoma. International Journal of Cancer 199353 278-284.

24 Bao L, Loda M, Janmey PA, Stewart R, Anand-Apte B \& Zetter BR. Thymosin $\beta$-15: a novel regulator of tumor cell motility upregulated in metastatic prostate cancer. Nature Medicine 19962 $1322-1328$

25 Califano D, Monaco C, Santelli G, Giuliano A, Veronese ML, Berlingieri MT et al. Thymosin $\beta-10$ gene overexpression correlates with the highly malignant neoplastic phenotype of transformed thyroid cells in vivo and in vitro. Cancer Research 1998 $58823-828$.

26 Conlon JM, Grimelius L, Wallin G \& Thim L. Isolation and structural characterization of thymosin $\beta 4$ from a medullary thyroid carcinoma. Journal of Endocrinology 1988118 155159.

27 Schuppert F, Reiser M, Heldin NE, Ede S, Scheumann GF, Dralle H \& von zur Muhlen A. Thyrotropin receptor and leukocyte adhesion molecules in autoimmune thyroid disease: a study of their gene expression by northern blot analysis and in situ hybridization. European Journal of Endocrinology 1994131 480-488.

28 Ambesi-Impiombato FS, Parks LAM \& Coon HG. Culture of hormone-dependent functional epithelial cells from rat thyroids. Proceedings of the National Academy of Sciences of the USA 198077 3455-3459.

29 Fusco A, Berlingieri MT, Di Fiore PP, Portella G, Grieco M \& Vecchio G. One- and two-step transformations of rat thyroid epithelial cells by retroviral oncogenes. Molecular and Cellular Biology 19877 3365-3370. 
30 Curcio F, Ambesi-Impiombato FS, Perrella G \& Coon HG. Long term culture and functional characterization of follicular cells from adult normal human thyroids. Proceedings of the National Academy of Sciences of the USA 19949 9004-9008.

31 Chomczynski P \& Sacchi N. Single-step method of RNA isolation by acid guanidinium thiocyanate-phenol-chloroform extraction. Analytical Biochemistry 1987162 156-159.

32 Chirgwin J M, Pryziyba AE, MacDonald RJ \& Ruttner WJ. Isolation of biologically active ribonucleic acid form sources enriched in ribonuclease. Biochemistry 197918 5294-5299.

33 Sambrook J, Fritsch EF \& Maniatis T. Molecular Cloning: A Laboratory Manual, Cold Spring Harbor, edn 2. New York: Cold Spring Harbor Laboratory Press, 1989.

34 Hunter T. Cooperation between oncogenes. Cell 199164 249-270.

35 Westermark B \& Porter KR. Hormonally-induced changes in the cytoskeleton of human thyroid cells in culture. Journal of Cell Biology $19829442-50$.
36 Nitsch L, Garbi C, Gentile R, Mascia A, Negri R, Polistina C et al. Physiological regulation and biological function of thyrotropin. Hormone and Metabolic Research 199023 32-37.

37 Yun K, Yamashita S, Izumi K, Yonemitsu N \& Sugihara H. Effects of forskolin on the morphology and function of the rat thyroid cell strain, FRTL-5: comparison with the effects of thyrotrophin. Journal of Endocrinology $1986111397-405$.

38 Yu FX, Lin SC, Morrison-Bogorad M \& Yin HJ. Effects of thymosin $\beta 4$ and thymosin $\beta 10$ on actin structures in living cells. Cell Motility and the Cytoskeleton 199427 13-20.

39 Muallem S, Kwiatkowska K, Xu X \& Yin HL. Actin filament disassembly is a sufficient final trigger for exocytosis in nonexcitable cells. Journal of Cell Biology 1995128 589-598.

Received 29 October 1998

Accepted 26 January 1999 